\title{
The Reaction of Barren-Ground Caribou to Aircraft
}

\author{
GEORGE W. CALEF ${ }^{1}$, ELMER A. DeBOCK ${ }^{2}$ and GRANT M. LORTIE
}

\begin{abstract}
The responses of barren-ground caribou to fixed-wing aircraft and to helicopters were observed in the northern Yukon and Alaska. Effects of aircraft altitude, type of aircraft, season and terrain were determined together with the activity and size of group of the caribou. Panic reactions or strong escape reactions were observed in a high percentage of all groups when aircraft flew at altitudes of less than 60 metres. Flying at a minimum aircraft altitude of 150 metres during spring and fall migrations, and 300 metres at other periods, would prevent the caribou reacting in the ways most immediately injurious to them.
\end{abstract}

RÉSUMÉ. Réactions du caribou de toundra aux appareils aéroportés. Les réactions du caribou de toundra aux avions et aux hélicoptères furent étudiées dans le Yukon du Nord et en Alaska. Les auteurs en déterminèrent les effets selon l'altitude, le type d'appareil, les saisons, le terrain, en même temps que l'activité et la dimension des groupes de caribous. Des réactions de panique ou de fortes réactions de fuite furent observées dans un pourcentage élevé de tous les groupes lorsque les appareils volaient à des altitudes inférieures à 60 mètres. En volant à des altitudes minima de 150 mètres en périodes de migration au printemps et en automne et de 300 mètres en tout autre temps, on éviterait des réactions du caribou qui lui soient le plus immédiatement nuisibles.

PE3ЮMЕ. Реакчия канадского северного оленя на самолеты. На северном Юконе и Аляске велись наблюдения за реакцией канадского северного оленя на появление самолетов и вертолетов. Был установлен характер поведения животных в группах различной величины в зависимости от высоты полтта и типа самолета, а также времени года и типа местности. В большинстве случаев животные впадали в панику или обращались в бегство, когда самолет пролетал на высоте ниже 60 м. Чтобы оградить животных от наиболее вредных для них реакций, самолетам не следует спускаться во время полета ниже 150 м в период весенней и осенней миградии и ниже 300 м в другое время года.

\section{INTRODUCTION}

Aircraft play a central role in transportation in the roadless areas of the Arctic and Subarctic. More and more of them will be operating in those regions as industrial activity, tourism and levels of human population increase there. How will these noisy intruders affect animals accustomed to the soft sounds of wilderness?

Barren-ground caribou (Rangifer tarandus) are especially likely to encounter, and perhaps be harassed by, aircraft. They range widely, and at times form large, conspicuous herds which attract the attention of curious people who encounter

\footnotetext{
1Fish and Wildlife Service, Department of Natural and Cultural Affairs, Government of the Northwest Territories, Yellowknife, N.W.T., Canada.

2Canadian Wildlife Service, Edmonton, Alberta, Canada.

${ }^{3}$ Game Branch, Department of Tourism, Information, and Conservation, Government of the Yukon Territory, Box 2703, Whitehorse, Y.T., Canada.
} 
them while working or travelling.

Aircraft may then be used to closely approach the animals so that the passengers may observe them or take photographs. Such close approaches may cause the animals to stampede or disturb them in more subtle ways.

During our studies of the distribution, movements, and behaviour of the Porcupine herd of barren-ground caribou in the northern Yukon, Alaska, and Northwest Territories (Fig. 1), we seized the opportunity to record the reaction of these animals to our aircraft in a variety of seasons and circumstances. From these observations we obtained some idea of the potential of aircraft to disturb caribou, and the rules of aircraft operation which would serve to reduce the injurious effects of such disturbances.

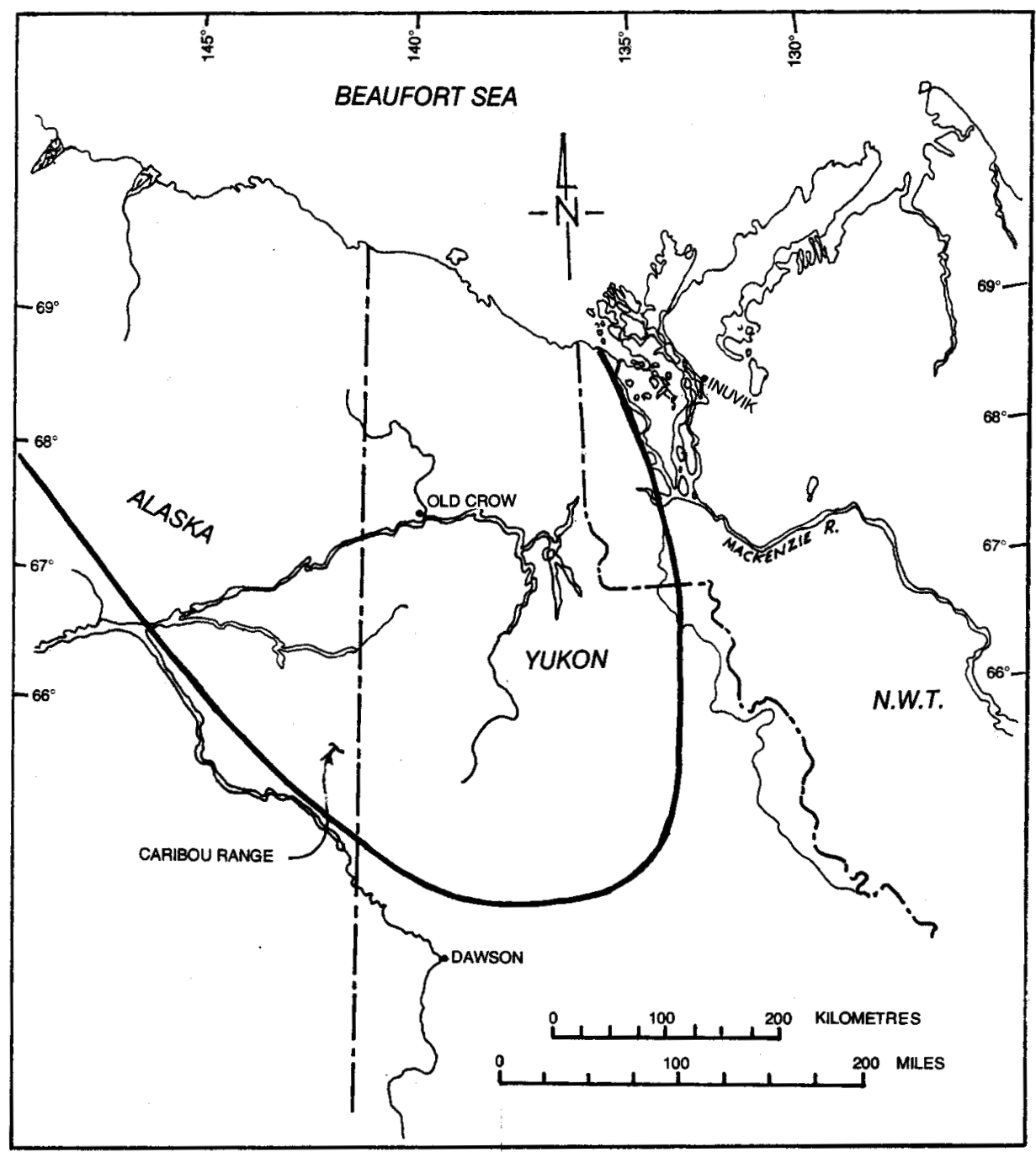

FIG 1. The study area. 


\section{METHODS}

Our observations of the reactions of caribou to aircraft were made during flights whose primary purpose was to locate, and enumerate, groups of caribou. The observations of Calef and Lortie were carried out independently of those by DeBock. The aircraft proceeded in level flight along predetermined courses. Whenever a group of animals was encountered, the following data were recorded: location; altitude of the aircraft above ground level (all references to aircraft altitude in this paper refer to altitude above ground level); horizontal distance from the aircraft to the caribou; number, sex, and age of caribou present; disposition and activity of the animals (such as feeding or resting on river ice, etc.); and vegetation type and nature of the topography.

We divided the reaction of caribou into five classes, as follows:

Class 1. Panic response. Animals were completely out of control; they stumbled, collided with one another, and ran into obstacles such as willow patches or trees. There was some subjectivity in distinguishing this class from the following one.

Class 2 . Strong escape response. Animals trotted or ran, and usually continued running after the aircraft had passed.

Class 3. Mild escape response. Animals moved away from the aircraft or from the original direction of movement in the case of travelling animals. This class included only animals which walked or trotted a short distance.

Classe 4. Stationary response. Animals stopped feeding; rose from resting position, or assumed alarm posture (Pruitt 1960).

Class 5. No visible response. Animals continued feeding or resting or, if moving, continued at the same pace in the same direction.

When not all animals in a group behaved in the same way, the reaction of the largest proportion of the animals was recorded as representing that of the group. If some animals in a single group were engaged in one type of activity (e.g., feeding) and others something else (e.g., sleeping) the reactions of both fractions of the group were recorded.

During the two years of the study (1972-73), we recorded the reactions of 736 groups of caribou, ranging in size from single individuals to several thousand animals, from four different types of aircraft (Table 1).

\section{RESULTS}

\section{Combining independent observations}

Since the studies of Calef and Lortie, and those by DeBock were done independently, when we wished to combine and compare our results we had to make sure that we were classifying caribou response in the same way; in other words, that we would observe similar behaviour under similar conditions.

Results obtained by Calef and Lortie during the fall migration in 1972 were similar to those obtained by DeBock during the fall migration in 1973 (Fig. 2). Both sets of observations indicated the same trend - a pronounced increase in panic and strong escape responses when the aircraft fiew lower than 200 feet 
FIG. 2. Fall migration. Percentages of caribou displaying (A) panic, (B) panic or a strong urge to escape, or $(C)$ any urge to escape, in response to aircraft flying at varying aititudes. The circles have reference to observations made by Calef and Lortie in 1972, the triangles to ones made by De Bock in 1973.
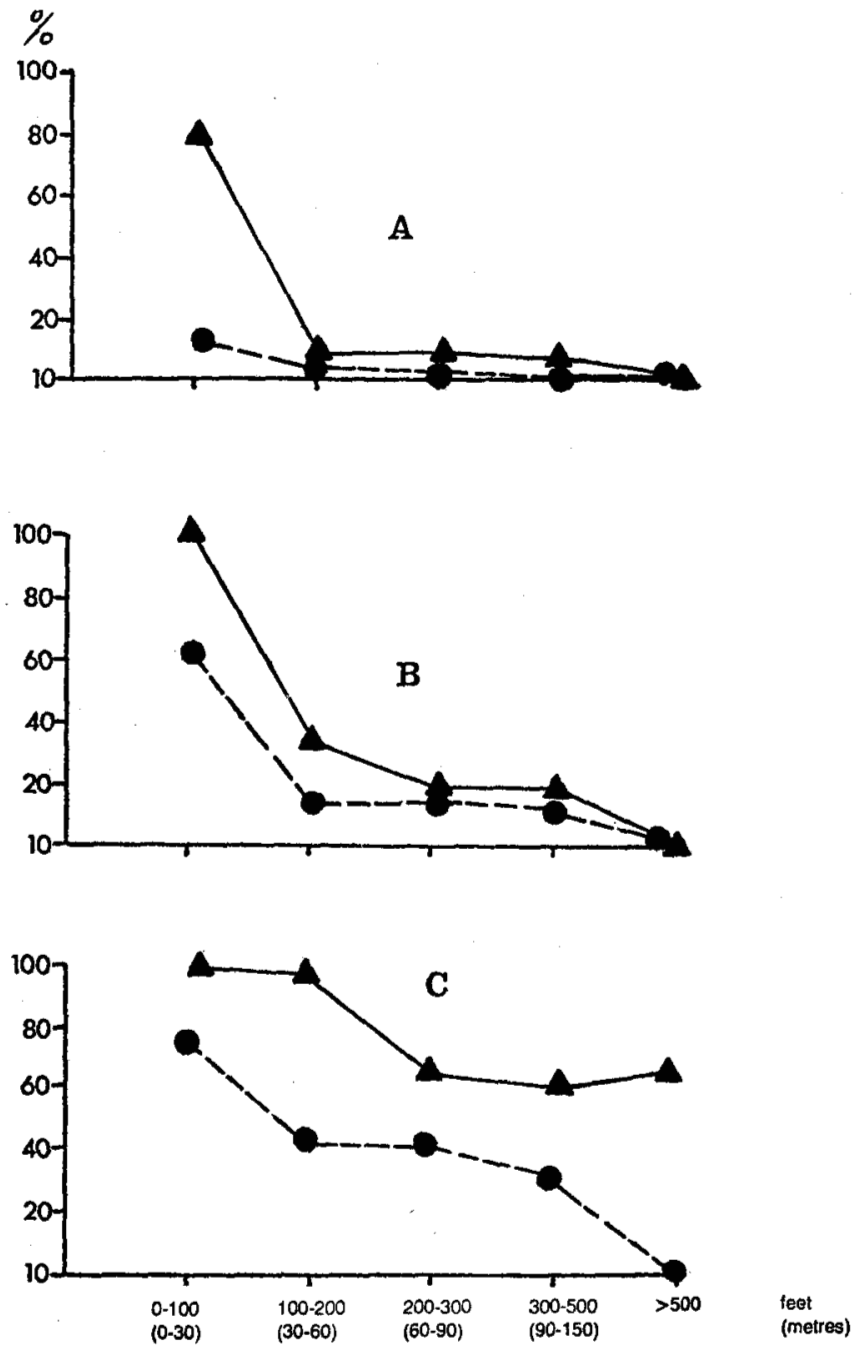

(60 m) - although DeBock's data indicated a consistently higher responsiveness of caribou in 1973 and there were significant differences in the observations at some altitudes. Both sets of data also indicate that, although panic and escape responses declined to less than $20 \%$ of all observations from altitudes above 200 feet, 30-65\% of the groups still exhibited some type of escape response for altitudes of up to 500 feet $(150 \mathrm{~m})$.

DeBock's data for spring migrations in 1972 and 1973 also showed that the animals were more reactive to aircraft in 1973 than in 1972 (Fig. 3). Again the trend of behaviour was similar in the two years despite significant differences at some altitudes. The important point is that there was as much variation between two years' observations made by DeBock on spring migration as there was between his observations and those of Calef and Lortie during two fall migrations. Moreover, the differences are all in one direction, indicating that the animals were 
FIG. 3. Spring

migrations. Percentages of caribou displaying

(A) panic, (B) panic or a strong urge to escape, or (C) any urge to escape, in response to aircraft flying at varying altitudes. The circles and triangles have reference to observations by De Bock in 1972 and 1973 respectively.
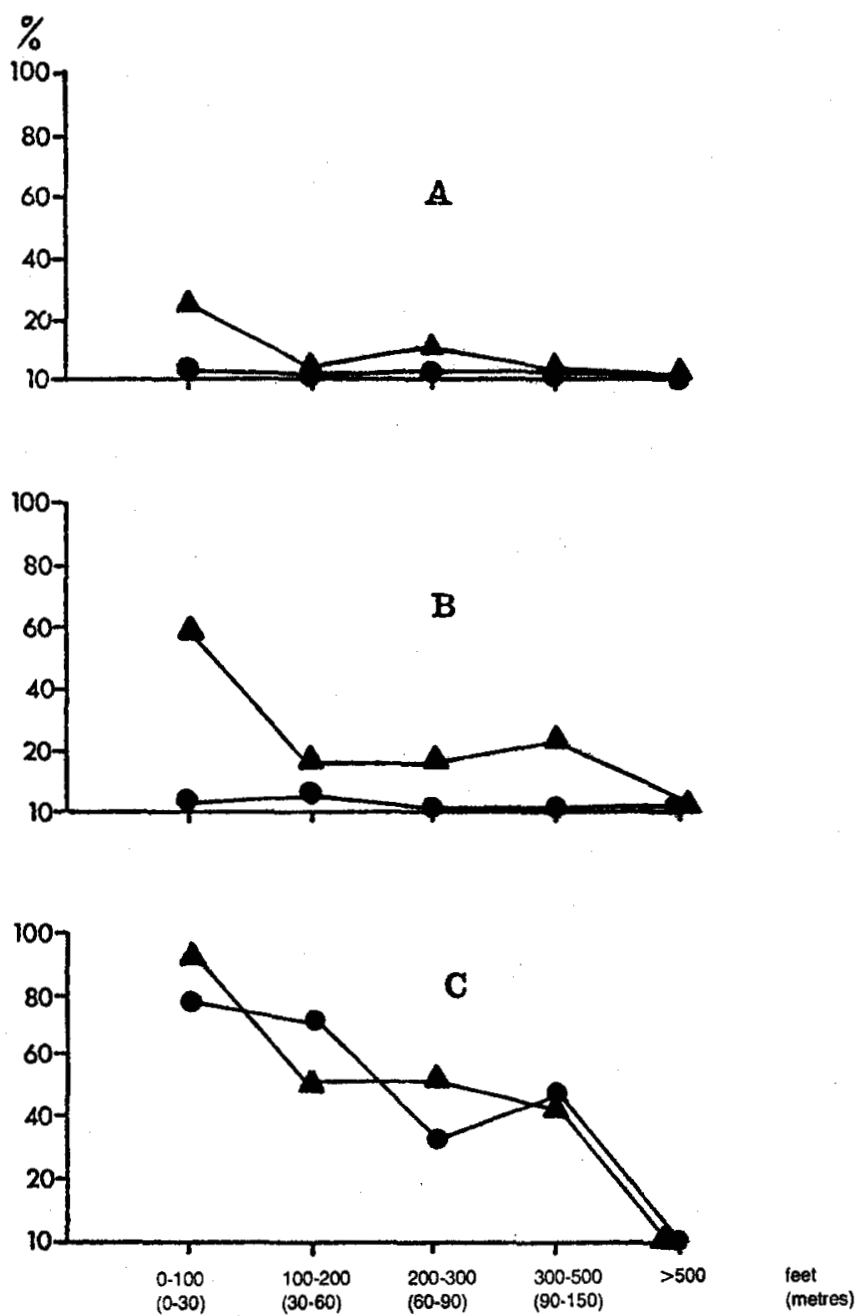

more reactive in 1973 than in 1972.

We have no explanation for the increase in reactivity in 1973 as compared with 1972. Perhaps the animals became sensitized to aircraft as a result of the frequent overflights they experienced during 1971 and 1972, when environmental studies on proposed gas pipeline routes were at their peak.

Since we independently observed similar trends in the response of caribou to aircraft, we feel that we can combine and compare our data. Any large differences in the reactions of caribou observed under different conditions (for example, at different times of the year) are likely to represent real differences in the animals' behaviour and not merely artefacts resulting from the subjectivity of independent observers.

\section{Seasonal variations}

When data from 1972 and 1973 are combined, it can be seen that during 
FIC. 4. Percentages of caribou displaying $(A)$ panic, (B) panic or a strong urge to escape, or (C) any urge to escape, in response to aircraft flying at varying altitudes at four different times of year (see LEGEND).
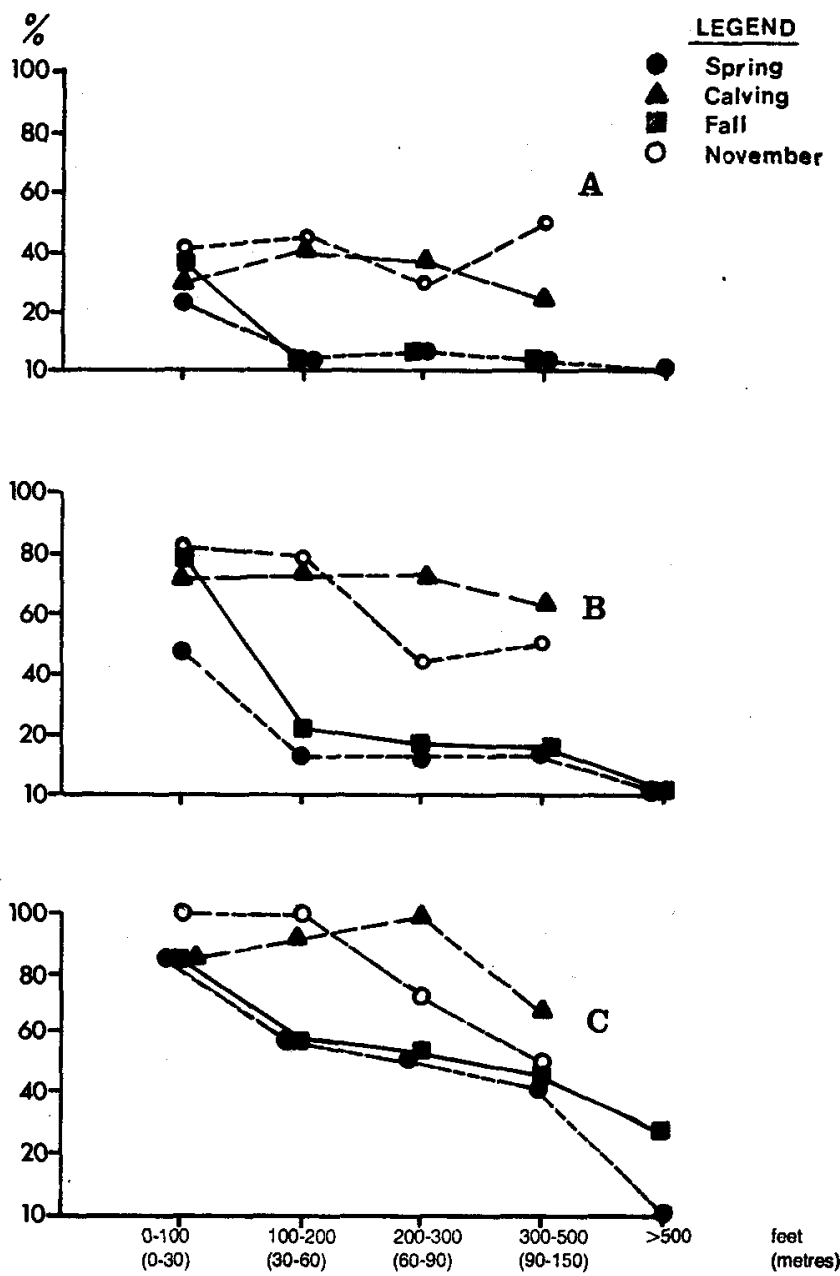

spring and fall migrations the response of caribou to aircraft was very similar (Fig. 4). At both these times of year, a high percentage of groups exhibited panic or strong escape responses when the aircraft was flying at a height of less than 200 feet $(60 \mathrm{~m})$. Above this altitude, the aircraft caused these responses in less than $20 \%$ of all groups observed. Above 500 feet $(150 \mathrm{~m})$, no panic or strong escape responses occurred, and even mild escape responses dropped to a low level.

Caribou display a different trend in behaviour when disturbed by aircraft on the calving grounds or during cold weather in early winter (Fig. 4). At these times of year there is a high percentage of panic and strong escape responses to be observed at all altitudes up to 500 feet. There is also little tendency for panic and strong escape responses to decrease as aircraft altitude increases. For example, when the aircraft was flying at 100-200 feet $(30-60 \mathrm{~m})$, panic or strong escape responses occurred among $72 \%$ of groups observed on the calving grounds, and among $78 \%$ of groups observed in November, but among less than $20 \%$ of the groups observed during spring and fall migrations. Sixty-two percent of all groups ob- 
TABLE I. Summary of observations

\begin{tabular}{|c|c|c|c|c|c|}
\hline $\begin{array}{l}\text { Life history } \\
\text { phase }\end{array}$ & Dates & Location & Observer & $\begin{array}{l}\text { Number } \\
\text { of } \\
\text { groups }\end{array}$ & Aircraft type* \\
\hline Spring migration & 16-28 May 1972 & $\begin{array}{l}\text { Porcupine River } \\
\text { drainage }\end{array}$ & DeBock & 168 & Cessna 185 \\
\hline Calving & 5-22 June 1972 & $\begin{array}{l}\text { Yukon; Alaska } \\
\text { North Slope }\end{array}$ & $\begin{array}{l}\text { Calef and Lortie } \\
\text { Calef and Lortie }\end{array}$ & $\begin{array}{r}158 \\
12\end{array}$ & $\begin{array}{l}\text { Bell } 206 \\
\text { Beaver }\end{array}$ \\
\hline Fall migration & 1 Sept.-16 Oct. 1972 & $\begin{array}{l}\text { Porcupine River } \\
\text { drainage }\end{array}$ & Calef and Lortie & 145 & Beaver \\
\hline Spring migration & 13-30 May 1973 & $\begin{array}{l}\text { Yukon; Alaska } \\
\text { North Slope }\end{array}$ & DeBock & 69 & $\begin{array}{l}\text { Cessna } 185 \text { and } \\
\text { PA-18 Supercub }\end{array}$ \\
\hline Calving & 1-30 June 1973 & $\begin{array}{l}\text { Porcupine River } \\
\text { drainage }\end{array}$ & DeBock & 48 & Cessna 185 \\
\hline Fall migration & 8 Sept.-31 Oct. 1973 & $\begin{array}{l}\text { Porcupine River } \\
\text { drainage }\end{array}$ & DeBock & 108 & Cessna 185 \\
\hline Early winter & 1-27 Nov. 1973 & $\begin{array}{l}\text { Ogilvie River } \\
\text { drainage }\end{array}$ & DeBock & 28 & Cessna 185 \\
\hline
\end{tabular}

*The Bell 206 is a small jet-turbine helicopter. The other three types listed are small, single-engine bush planes powered by piston engines.

served from altitudes of $300-500$ feet $(90-150 \mathrm{~m})$ on the calving grounds still exhibited panic or strong escape responses. Groups observed in November showed a slightly greater decline in panic and strong escape responses with increasing aircraft altitude than did those on the calving grounds.

\section{Reactions to helicopters as compared to fixed-wing aircraft}

On the calving grounds we made observations from both jet-turbine helicopters and fixed-wing aircraft (Table 1). The animals reacted less violently to the helicopter than to the fixed-wing (Fig. 5). Escape or strong panic reactions were noted in $65-75 \%$ of all groups observed from the fixed-wing aircraft at altitudes of up to 500 feet, but in only $10-25 \%$ of all groups observed from the helicopter. For both types of aircraft there was only a slight tendency for the percentage of panic and strong escape responses to decrease with increasing altitude of the aircraft up to 500 feet.

\section{Influence of caribou activity, group size and terrain}

The activity of caribou at the time of observation influenced their response to the aircraft (Fig. 6). Travelling and feeding animals were similar in their level of response. Caribou at river crossings were more reactive than were travelling or feeding animals, and resting animals were less reactive.

Neither the size of the group of caribou (Fig. 7) nor the terrain and vegetation type in which they were observed exhibited any significant effect on their response to aircraft.

\section{Additional observations}

On two occasions we observed the birth of calves during aerial surveys. In both cases, despite several low passes at an altitude of 100-200 feet $(30-60 \mathrm{~m})$, the cows paid no attention to the aircraft, but devoted full attention to licking and 
FIG. 5. Percentages of caribou displaying (A) panic, (B) panic or a strong urge to escape, or (C) any urge to escape, in response to fixed-wing aircraft (squares) or turbine helicopters (circles) at varying altitudes.
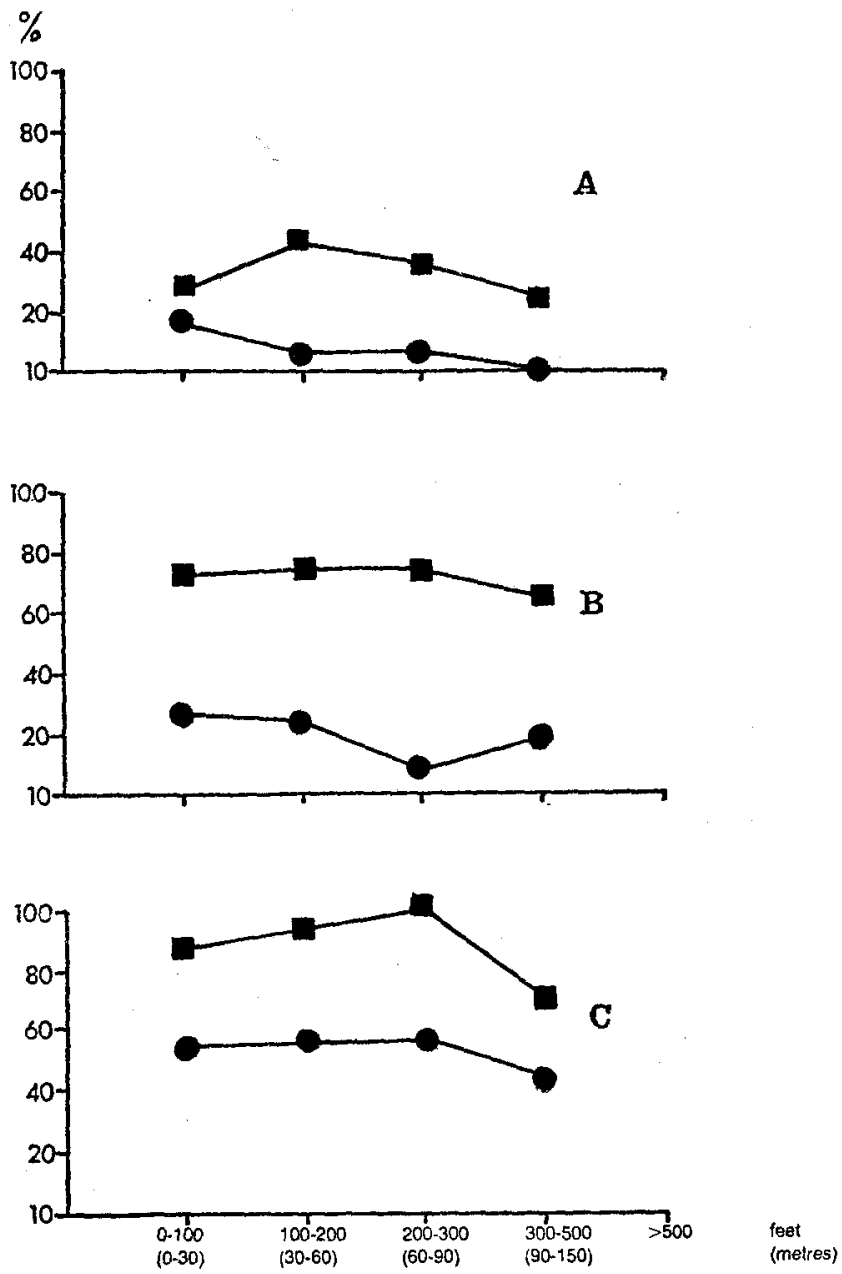

attending the newborn calves. On two other occasions, when helicopters landed near calves which could not follow their mothers (one still-born, one sick), the females remained with or near the calves despite the presence of the helicopter. In another case, a cow with a still-born calf remained despite the nearby operation of two helicopters at low altitude. Thus, except for cases of extreme and purposeful harassment, aircraft overflights do not seem to cause cows to abandon calves.

Calves responded to aircraft more than did other classes of caribou during both spring and fall. In spring, young calves invariably ran to their mothers, even when the latter made no overt response to their aircraft. This was true to a lesser degree in the autumn. Cows with calves were apparently no more sensitive to aircraft disturbance than other caribou in the autumn.

On several occasions when flying near large herds of caribou $(10,000-60,000)$ during the period of insect harassment in July, we found we could herd the caribou in given directions by circling them at altitudes of 700-2,000 feet $(215-610 \mathrm{~m})$. Just before the rut in 1972, we observed on one occasion caribou which seemed 
FIG. 6. Percentages of caribou displaying panic or a strong urge to escape while engaged in different types of activity (see . LEGEND), in response to aircraft flying at varying altitudes.

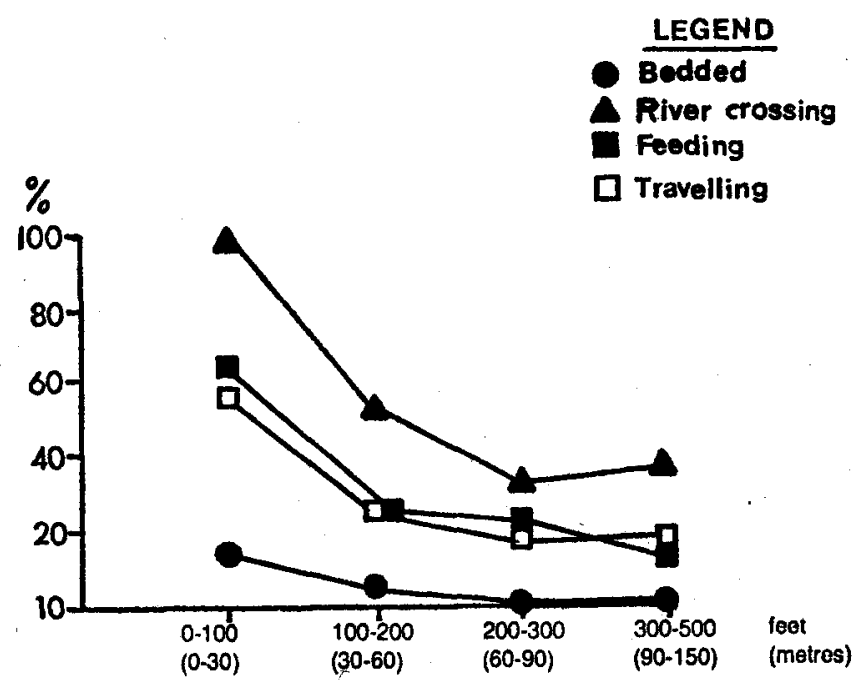

FIO. 7. Percentages of caribou displaying (A) panic or a strong urge to escape, or (B) any urge to escape, according to size of group (see LEGEND), in response to aircraft flying at varying altitudes.
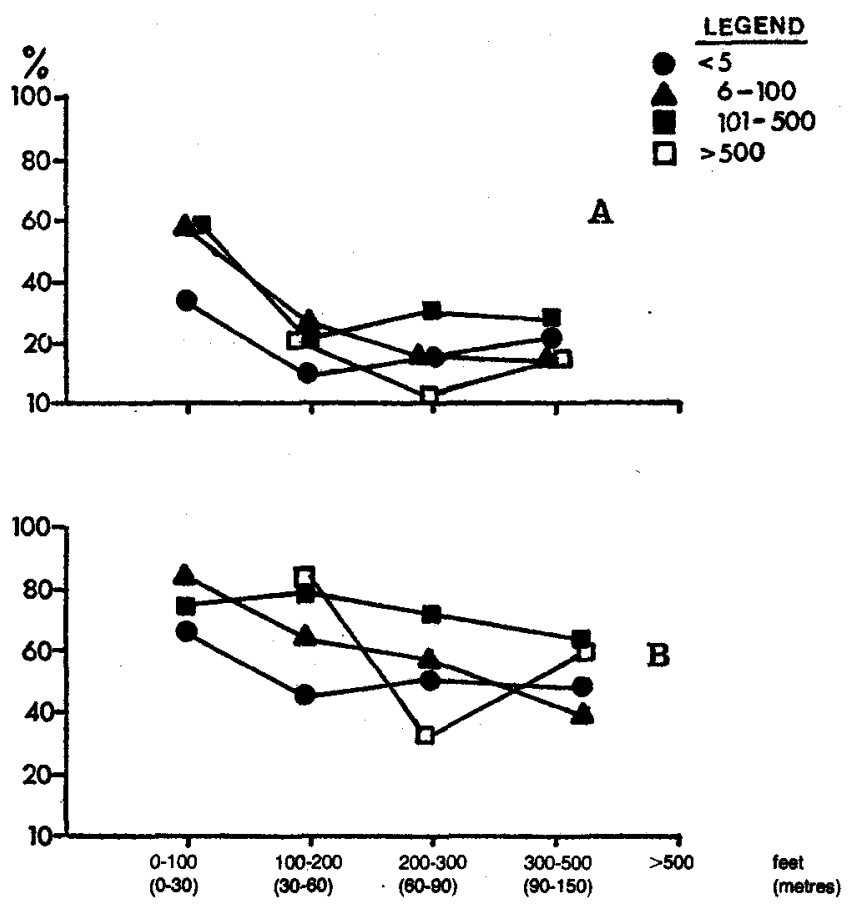

to be responding to the aircraft at greater distances than they had earlier during the autumn migration. Large groups of animals crossing small lakes broke into a hard sustained run as the aircraft circled at elevations of more than $\mathbf{3 0 0}$ feet and distances greater than a quarter of a mile. This running often persisted long after the aircraft had left the area. The increase in sensitivity may have been due to the approach of the rut. An increased sensitivity to aircraft during the rut among the semi-domestic reindeer of the Mackenzie Delta herd has been noted by $R$. Nowosad 
who carried out studies for the Canadian Wildlife Service (personal communication, 1972.)

\section{DISCUSSION}

\section{Effects of disturbance by aircraft}

Aircraft disturbance is merely one of many results of human activity which could have a variety of deleterious effects on caribou. These effects can be divided into three categories:

1. Those causing immediate physical injury or death.

2. Those resulting in increased expenditures of energy, or changes in the physiological condition of the animals, which reduce their rates of survival or reproduction.

3. Those resulting in long-term changes in behaviour, including, especially, the traditional use of ranges.

Low level flight or "buzzing" elicits panic responses from caribou, which may then injure themselves by stumbling or colliding with one another. Cows just before parturition, and young calves, are particularly susceptible to such injury. Sustained running results in an unusual depletion of energy reserves which could be particularly harmful during periods of stress such as late winter or when the caribou are being harassed by insects. Running during cold weather promotes pulmonary disorders in reindeer (Zhigunov 1968), and therefore presumably in caribou. These are the obvious and immediately injurious consequences to caribou of their making sustained escape responses.

The long-term and more subtle effects of aircraft disturbance cannot be predicted at present. Some species such as wolves can become completely habituated to aircraft according to G. Haber who studied wolves in McKinley National Park, Alaska (G. Haber, personal communication, 1972). On the other hand, repeated disturbance by aircraft could cause animals to abandon a range, as automobile and railway traffic apparently have caused them to do in Norway (Klein 1971). Furthermore, little is known of the long-term effects of disturbance on the physiology of ungulates. Geist (1971) has cited several examples of long-term deleterious effects on metabolism and hormone balance of ungulates exposed to disturbance.

\section{Avoidance of injury to caribou}

It is panic and strong escape responses, according to our classification, which would result in caribou injuring or exhausting themselves. Clearly, when aircraft operate in areas inhabited by caribou they should do so in ways which at least do not give rise to injurious responses. Our data indicate that if aircraft operate at heights above 500 feet $(150 \mathrm{~m})$, in level flight, during the spring or fall migration, most potentially injurious reactions by caribou will be avoided. To completely avoid the possibility of even mild escape responses would necessitate aircraft flying even higher, to 1,000 feet. During the calving period and in early winter, and often during the rut, a substantial percentage of strong escape responses occurred when the aircraft was flying at $300-500$ feet $(90-150 \mathrm{~m})$. To avoid the 
possibility of injury or other immediate harmful effects to caribou at these times, a minimum altitude of 1,000 feet $(305 \mathrm{~m})$, would be required. Long-term physiological or behavioural changes might still result from repeated aircraft disturbance, however, even if these altitude requirements were observed.

It is generally considered that helicopters frighten animals more than do fixed-wing aircraft. Our observations made at calving time did not, however, bear out this belief; and limited observations made at other times of the year have indicated that helicopters are no more disturbing than fixed-wing aircraft. Therefore, the above altitude recommendations should apply equally to helicopters and fixed-wing aircraft.

Of course, helicopters have a greater potential for harassing animals than do fixed-wing aircraft. During our studies of calf productivity, we often used a helicopter for counting the calves present in a small group of caribou. We found that, if we slowly circled groups of cows and calves so that they were always turning away from the aircraft we rarely observed strong escape responses. In fact, we often had to make two or three circles before the animals got to their feet and moved. However, if the helicopter stayed behind the animals once they started to move in a given direction, and kept following them, then extreme panic reactions resulted. Following is the most dangerous form of harassment, and is possible only with a helicopter.

\section{COMPARISONS WITH OTHER STUDIES}

Other recent observations of the reaction of caribou to aircraft have been made in the northern Yukon and northeastern Alaska (Klein 1973; McCourt et al. 1974; McCourt and Horstman 1974). Klein used the same categories of response and aircraft altitude as are reported upon in the present paper, and so his results are directly comparable to ours. He witnessed substantially the same degree of reaction among the caribou in spring and summer as we did. However, he concluded that helicopters frightened the animals more than did fixed-wing aircraft during these periods.

The results of studies by McCourt et al. (1974) and McCourt and Horstman, (1974) are more difficult to compare with ours because they concerned diagonal distance between the aircraft and the caribou, whose responses were divided into only three categories. However, the results appear to differ from ours in many respects.

McCourt et al. (1974) presented the following conclusions which differ from ours:

1. Caribou reacted more violently to a helicopter than to a fixed-wing aircraft.

2. Bedded and feeding animals reacted more strongly than did animals engaged in other activities.

3. There was a correlation between group size and degree of reaction, with large groups reacting more.

McCourt and Horstman (1974) presented a detailed statistical analysis of over 4,000 observations of disturbances caused to caribou by aircraft. This analysis also showed that reactions varied with size of group. The same authors also 
presented a somewhat different picture of seasonal variation in degree of reaction, concluding in particular that caribou were less reactive on the calving grounds.

The reasons for these differing conclusions are not clear, especially since the respective studies were carried out on the same caribou herd during the same years. What is important, however, is that there seems to be general agreement that if aircraft do not operate at heights below 1,000 feet (approx. $300 \mathrm{~m}$ ) above ground level, most injurious reactions by caribou will be avoided.

\section{ACKNOWLEDGEMENTS}

The work of Calef and Lortie was carried out for the Environment Protection Board, and funded by Gas Arctic Study Ltd. DeBock's work was funded in part by the Canadian Wildlife Service, and in part by the Environment-Social Program of the Department of Indian and Northern Affairs of the Canadian government. Don Gill and Ian McTaggart-Cowan read the manuscript and offered helpful suggestions. We thank all the pilots who flew us so skilfully and safely during our studies of the caribou.

\section{REFERENCES}

GEIST, v. 1971. A behavioral approach to the management of ungulates. In: Duffey, E. and Watt, A. S. (eds.), The Scientific Management of Animal and Plant Communities for Conservation, Oxford: Blackwell Scientific Publications.

KLEIN, D. R. 1971. Reaction of reindeer to obstructions and disturbances. Science, 173:393-8. 1973. The reaction of some northern mammals to aircraft disturbance. Proceedings, 11th International Congress of Game Biologists, Stockholm, 1973.

MCCOURT, K. H., FEIST, J. D., DOLL, D. and RUSSELL, J. 1974. Disturbance Studies of Caribou and Other Mammals in the Yukon and Alaska, 1972. Calgary: Canadian Arctic Gas Study Limited (Biological Report Series, vol. 5).

MCCOURT, K. H. and HORSTMAN, L. P. 1974. The reaction of barren-ground caribou to aircraft. In: Jakimchuk, R. D. (ed.), The Reaction of Some Mammals to Aircraft and Compressor Station Noise Disturbance, Calgary: Canadian Arctic Gas Study Limited (Biological Report Series, vol. 23).

PRUITT, W. O., JR. 1960. Behaviour of the Barren-ground Caribou. College, Alaska: University of Alaska (Biological Paper no. 3).

Zhigunov, P. s. (ed.) 1968. Reindeer Husbandry. (Translated from Russian). Jerusalem: Israel Program for Scientific Translation. 